\title{
Sheep and goats raised in mixed flocks have diverse immune status around parturition
}

\author{
Lorenzo E. Hernández-Castellano, ${ }^{1 *}$ Isabel Moreno-Indias, ${ }^{2,3}$ Davinia Sánchez-Macías, ${ }^{4}$ \\ Antonio Morales-delaNuez, ${ }^{5}$ Alexandr Torres, ${ }^{6}$ Anastasio Argüello, ${ }^{7}$ and Noemí Castro ${ }^{7}$ \\ ${ }^{1}$ Department of Animal Science, AU-Foulum, Aarhus University, 8830 Tjele, Denmark \\ ${ }^{2}$ Unidad de Gestión Clínica de Endocrinología y Nutrición, Laboratorio del Instituto de Investigación Biomédica de Málaga (IBIMA), \\ Hospital Universitario de Málaga (Virgen de la Victoria), Universidad de Málaga, 29010 Málaga, Spain \\ ${ }^{3}$ Centro de Investigación Biomédica en Red de Fisiopatología de la Obesidad y la Nutrición (CIBERObn), 28029 Madrid, Spain \\ ${ }^{4}$ Animal Production and Industrialization Unit, Department of Agroindustrial Engineering, Universidad Nacional de Chimborazo, \\ 060150 Riobamba, Ecuador \\ ${ }^{5}$ Agrobiotechnology Group, Instituto de Productos Naturales y Agrobiología, IPNA, CSIC Spanish Research Council, 38206 La Laguna, \\ Tenerife, Spain \\ ${ }^{6}$ Instituto Canario de Investigaciones Agrarias, 38200 La Laguna, Tenerife, Spain \\ ${ }^{7}$ Animal Production and Biotechnology Group, Institute of Animal Health and Food Safety, Universidad de Las Palmas de Gran Canaria, \\ 35413 Arucas, Gran Canaria, Spain
}

\section{ABSTRACT}

Several physiological and metabolic changes take place in dairy ruminants around parturition (late pregnancy, parturition, and early lactation). Dairy species are genetically selected for their higher milk production compared with non-dairy species. This fact causes a constant stress that impairs the immune status of the animal, with consequences for its welfare and performance. In the present study, we assessed the immune status of high-yield dairy sheep and goats by quantifying $\mathrm{IgG}$ and IgM concentrations, as well as chitotriosidase (ChT) and complement system [total complement system (TC) and alternative complement pathway (AC)] activity in blood plasma around parturition. We also measured IgG and IgM concentrations and ChT activity in colostrum and milk during the first $40 \mathrm{~d}$ postpartum. The lowest blood IgG concentration was at parturition in both species. We detected no differences in blood IgG concentrations between species. Blood IgM concentrations were constant in both species throughout the study period. However, blood IgM concentrations were greater in sheep than in goats. Blood ChT activity was greater in goats than in sheep, and both species showed constant activity of this enzyme throughout the study period. We observed no differences in complement system (TC and AC) activity between sheep and goats. In addition, both $\mathrm{TC}$ and $\mathrm{AC}$ activity were constant in both species throughout the experiment. In general, IgG and IgM concentrations were greater in sheep co-

Received April 2, 2019.

Accepted May 6, 2019.

*Corresponding author: lhc@anis.au.dk lostrum than in goat colostrum, but these differences disappeared after d 4 (IgG) and d 3 (IgM) postpartum. In both species, the highest IgG and IgM concentrations were measured in colostrum, gradually decreasing during the first days postpartum. Chitotriosidase activity decreased in both species from colostrum to milk, although goats always showed greater ChT activity than sheep. Both sheep and goats seemed to be more susceptible to infectious diseases around parturition. As well, goats showed greater ChT activity in blood, colostrum, and milk than sheep. This fact may give these animals additional protection against parasite and fungal infections.

Key words: immunoglobulin, chitotriosidase, complement system, sheep, goat

\section{INTRODUCTION}

Consumption of milk and dairy products from small ruminants (sheep and goats) has increased worldwide (Lérias et al., 2014). Moreover, small ruminants play an essential role in the conservation and rehabilitation of natural resources in developed countries (Castel et al., 2010), where sheep and goats are usually reared together in mixed flocks, under similar management and environmental conditions (Diakoua et al., 2013).

Over the years, small dairy ruminants have been selected for their high milk production (Søndergaard et al., 2002; Lérias et al., 2013). High milk output often increases metabolic load, especially during the transition period. In dairy cows, the transition period is commonly defined as the period between 3 wk prepartum and 3 wk postpartum (Grummer, 1995), when cows are often under a negative energy balance because of 
reduced feed intake capacity and increased energy output (Hernández-Castellano et al., 2017a; Weaver et al., 2017). Negative energy balance during the transition period has severe consequences for the metabolism, immune system, and performance of dairy cows (Esposito et al., 2014; Wankhade et al., 2017). In small dairy ruminants, few studies focusing on immune status around parturition (late pregnancy, partum, and early lactation) are available in the literature (Castro et al., 2006; Rodinova et al., 2008; Chniter et al., 2016). As described in dairy cows, the immune system is directly affected by negative energy balance around parturition (Esposito et al., 2014; Wankhade et al., 2017). Therefore, other components of the immune system may be also affected during this time. Chitotriosidase (ChT) is an important component of innate immunity against chitin-containing pathogens (Argüello et al., 2008), being able to cleave chitin present in the cell walls of fungi and nematodes (Renkema et al., 1998). The complement system is involved in specific and nonspecific immunity (Nesargikar et al., 2012), playing a crucial role in host defense mechanisms against external agents. The complement system is integrated by the classical complement pathway and the alternative complement pathway. Complete knowledge of changes in these immune variables in sheep and goats around parturition is indispensable for establishing proper management strategies in mixed flocks. This study aimed to describe changes in blood immune variables (IgG and IgM concentrations, ChT activity, and complement system activity) around parturition, as well as changes in colostrum and milk immune variables (IgG and IgM concentrations and ChT activity) during early lactation in sheep and goats.

\section{MATERIALS AND METHODS}

The present study was performed at the Universidad de Las Palmas de Gran Canaria (Spain) on 12 estrous synchronized Majorera goats and 12 estrous synchronized Canaria sheep during late pregnancy (2 wk prepartum), parturition, and early lactation (up to d 40 postpartum). The Majorera goat is the second-highest milk-yielding breed in Spain, producing $500 \mathrm{~kg}$ of milk during a lactation period of 210 d (Fresno et al., 1994; Lérias et al., 2013). The Canaria sheep is one of the high-yield sheep breeds in Spain, with a milk production of $1.8 \mathrm{~L} / \mathrm{d}$ and a lactation period of 180 to $200 \mathrm{~d}$ (Piñan, 2010; Hernández-Castellano et al., 2014a).

In this study, animals showed no symptoms of illness. Animal procedures were approved by the Ethical Committee for Animal Welfare (Universidad de Las Palmas de Gran Canaria, Spain).

\section{Housing}

Sheep and goats were placed in 2 separate pens with free water access, providing at least $1.7 \mathrm{~m}^{2}$ of floor space per animal. Sheep and goats were fed corn, soybean meal (CP 44\%), dehydrated alfalfa, dehydrated beetroot, alfalfa hay, and a vitamin-mineral supplement according to the guidelines issued by INRA (2007).

\section{Blood, Colostrum and Milk Sample Collection}

To ensure blood sample collection on d 15 and d 7 prepartum, blood samples were collected on d 17, 16, $15,14,13,9,8,7,6$, and 5 before expected parturition. Additional blood samples were then collected at parturition (d 0) and on d 5, 10, 20, 30, and 40 postpartum. All blood samples were collected at $0745 \mathrm{~h}$ from the jugular vein in 2.5-mL tubes with K-EDTA. Blood was centrifuged at 2,190 $\times \mathrm{g}$ for $15 \mathrm{~min}$ at $4^{\circ} \mathrm{C}$ (Universal 32 R; Hettich-Zentrifugen, Tuttlingen, Germany) and the resulting plasma was then alliquoted and stored at $-80^{\circ} \mathrm{C}$. Colostrum samples $(50 \mathrm{~mL})$ were collected at parturition (d 0). Transition milk samples $(50 \mathrm{~mL})$ were collected on d 1 and 2 postpartum. Similarly, milk samples $(50 \mathrm{~mL})$ were collected on d $3,4,5,10,20,30$, and 40 postpartum. Sheep and goats were milked once daily (from 0800 to $0830 \mathrm{~h}$ ) in a double 12-stall parallel milking parlor (Alfa Laval Iberia SA, Madrid, Spain) equipped with recording jars $(3.5 \mathrm{~L})$ and a low-line milk pipeline. Colostrum and milk samples were collected from the recording jars and then stored at $-80^{\circ} \mathrm{C}$.

\section{Immune Variables}

To determine blood plasma, colostrum, and milk IgG and IgM concentrations, we used commercial ELISA kits (Bethyl Laboratories, Montgomery, TX). We used purified sheep $\operatorname{Ig} G$, goat $\operatorname{IgG}$, sheep $\operatorname{IgM}$, and goat IgM as standard references. Samples were individually analyzed in triplicate, and a valid result was considered when differences were less than $10 \%$. Results were expressed as milligrams of Ig per milliliter in plasma, colostrum, and milk. Chitotriosidase activity was measured following the procedure described by Argüello et al. (2008). Samples were individually analyzed in triplicate, and a valid result was considered when differences were less than 10\%; ChT activity was expressed in micromoles of substrate hydrolyzed per milliliter per hour. We measured total complement system (TC) activity (classical complement pathway + alternative complement pathway) and alternative complement pathway (AC) activity in blood plasma using the technique described by Moreno-Indias et al. (2012a). Both TC and 
AC activity were expressed as percentage of hemolysis in fresh rabbit red blood cells.

\section{Statistical Analyses}

All results are presented as mean \pm standard error of the mean. We performed statistical analyses using SAS version 9.4 (SAS Institute Inc., Cary, NC). We used the MIXED procedure to evaluate changes during the experimental period (from $\mathrm{d}-15$ to $\mathrm{d} 40$ relative to parturition), as well as differences between species (Majorera goat vs. Canaria sheep). The final model included species, experimental period, and the interaction between both as dependent variables, and animal as repeated subject. Finally, we used the Tukey-Kramer test to evaluate differences between groups. Values were considered significant at $P<0.05$.

\section{RESULTS}

\section{Immune Variables in Blood}

We found no differences in blood IgG concentrations (Figure 1A) between sheep and goats throughout the experimental period. Both species showed the lowest blood IgG concentrations from d -15 to parturition $(P<0.05)$; concentrations increased progressively postpartum. Goats reached their highest IgG concentration on d 20 postpartum $(P<0.05)$, and sheep on d 40 postpartum $(P<0.05)$. Blood IgM concentrations (Figure 1B) were greater in sheep than in goats throughout the experimental period $(P<0.05)$, although we detected no differences within species $(P>0.05)$. Blood ChT activity (Figure 1C) was greater in goats than in sheep throughout the experimental period $(P<0.05)$. Both species showed constant activity of this enzyme in blood throughout the experiment, with the exception of d 40 postpartum, when ChT activity increased in both species $(P<0.05)$. We found no differences in the complement system activity (TC and $\mathrm{AC}$ ) between sheep and goats throughout the experimental period (Figure 1D and 1E, respectively). Both species showed constant TC and AC activity throughout the experiment.

\section{Immune Variables in Colostrum and Milk}

We observed no differences in IgG concentrations (Figure 2A) between sheep and goats at parturition and on $\mathrm{d} 1$ postpartum $(P>0.05)$. However, sheep transition milk showed greater IgG concentrations than goat transition milk on d 2 postpartum $(P<0.05)$. Sheep milk showed greater IgG concentration than goat milk on $\mathrm{d} 3$ and d 4 postpartum $(P<0.05)$, but we detected no differences between groups for the rest of the experimental period $(P<0.05)$. In both species, the highest IgG concentrations occurred in colostrum at parturition $(P<0.05)$, decreasing gradually until $\mathrm{d}$ 4 postpartum, when they remained constant until the end of the experimental period. We found that IgM concentrations (Figure 2B) were greater in sheep than in goats from parturition to d 3 postpartum $(P<0.05)$. Colostrum IgM concentrations decreased in both species and reached constant values on d 4 postpartum in sheep and on d 2 postpartum in goats. Chitotriosidase activity (Figure 2C) was greater in goat colostrum and milk than in sheep colostrum and milk $(P<0.05)$. Both species showed the highest ChT activity in colostrum at parturition $(P<0.05)$, decreasing during the rest of the studied period.

\section{DISCUSSION}

The period around parturition is one of the most challenging and critical periods during the lactation cycle in both large and small dairy ruminants (Manat et al., 2016; Weaver et al., 2017). During this period, major physiological, nutritional, and metabolic changes may affect immune status in these animals with severe consequences for animal welfare and performance.

In our study, blood IgG concentrations were lowest in both species around parturition (i.e., from d 15 to parturition) as previously described in blood from sheep and goats, respectively (Ciupersescu, 1977; Castro et al., 2011). Similarly, Herr et al. (2011) observed how blood IgG concentrations decreased in Holstein cows around parturition. In agreement with our results, these authors did not detect changes in blood IgM concentrations during this period. As suggested by Hurley and Theil (2011), most IgG in cow colostrum is directly transferred from blood, with low IgG synthesis by intraepithelial lymphocytes in the mammary tissue. These authors also described how most of the IgM content in colostrum is directly synthesized by these lymphocytes, with a low amount of IgM directly transferred from blood. According to our results, it appears that a similar mechanism also occurs in dairy sheep and goats around parturition. This could explain the decreased blood IgG concentrations and constant blood IgM concentrations observed in both species around parturition.

Malaguarnera et al. (2006) indicated that ChT plays an important role in immune response and other inflammatory processes, because ChT can cleave chitin present in the cell wall of fungi and nematodes (Renkema et al., 1998). In ruminants, ChT activity was first described in adult goats by Argüello et al. (2008). However, and to the best of our knowledge, sheep ChT 
activity has only been described in blood from newborn lambs (Hernández-Castellano et al., 2015a,b); the present study is the first time the activity of this enzyme has been described. Although goat ChT activity was greater than values in a previous study (Argüello et al., 2008; $2.95 \mu \mathrm{mol} / \mathrm{mL}$ per hour at partum), the authors of that study did not find differences in the activity of this enzyme during the peripartum period (from $d$ -3 prepartum to d 4 postpartum), in agreement with the present results. Based on our results, it seems that the goat breed we used in this study (Majorera) is better protected against fungi and nematodes around parturition than the sheep breed we used (Canaria). This statement is in agreement with epidemiological studies performed in sheep and goats by Thomas et al. (2007) and Getachew et al. (2017). Specifically, Thomas et al. (2007) found higher prevalence of Haemonchus spp. and Trichostrongylus axei infections in
A

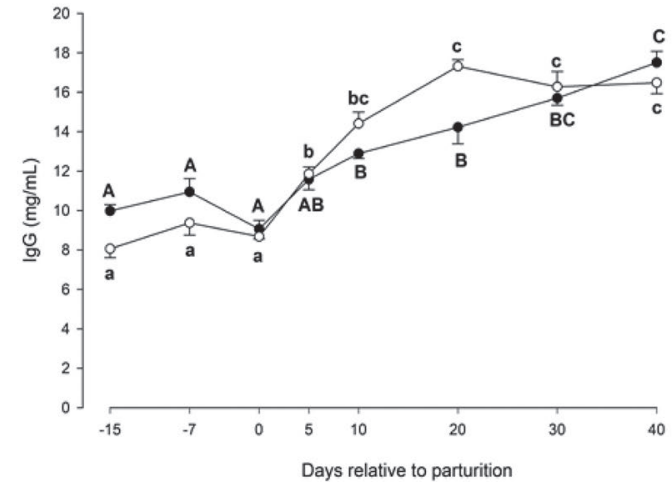

C

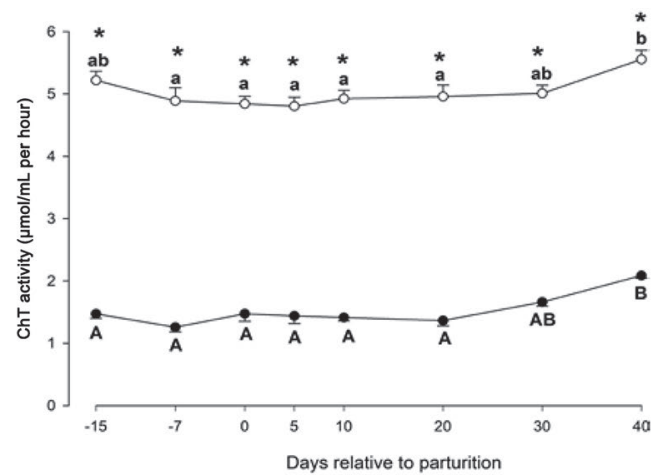

$\mathrm{E}$

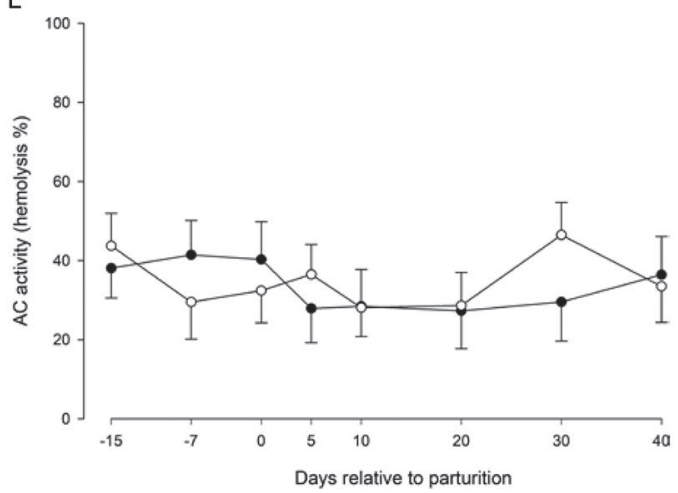

B

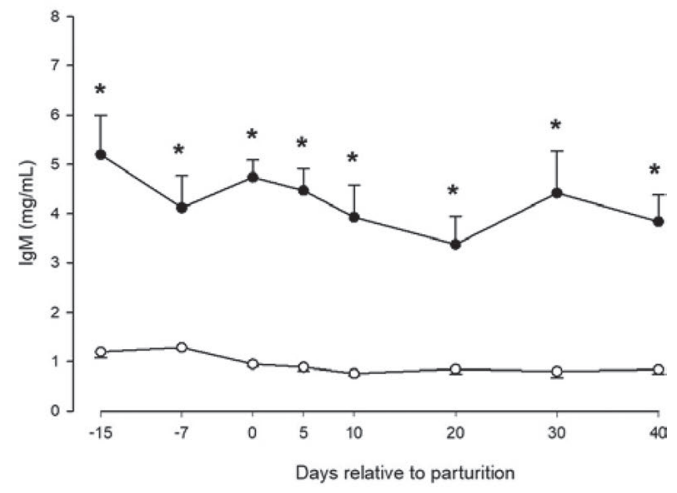

D

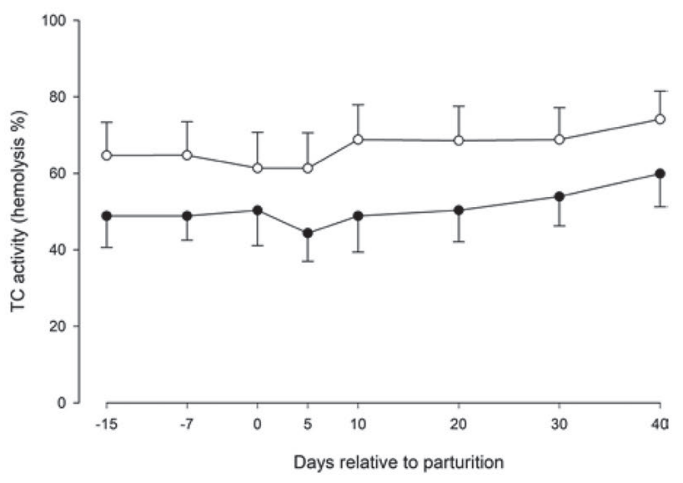

Figure 1. Concentrations of blood plasma IgG (A) and IgM (B) and activities of chitotriosidase (ChT; C), total complement system (TC; D) and alternative complement pathway (AC; E) in Canaria sheep $(\bullet)$ and Majorera goats $(O)$ during the experimental period. Different uppercase letters $(\mathrm{A}-\mathrm{C})$ indicate significant differences $(P<0.05)$ between time points in Canaria sheep. Different lowercase letters $(\mathrm{a}-\mathrm{c})$ indicate significant differences $(P<0.05)$ between time points in Majorera goats. ${ }^{*}$ Indicates a significant difference $(P<0.05)$ between Canaria sheep and Majorera goats at each time point. Data are mean \pm SEM. 
A

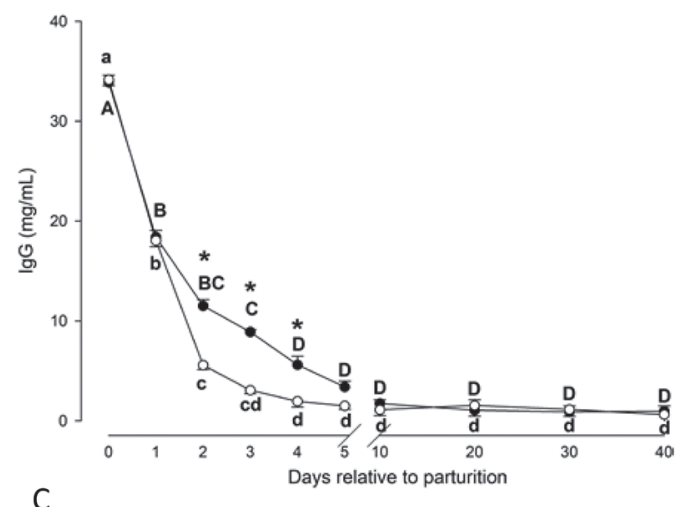

C

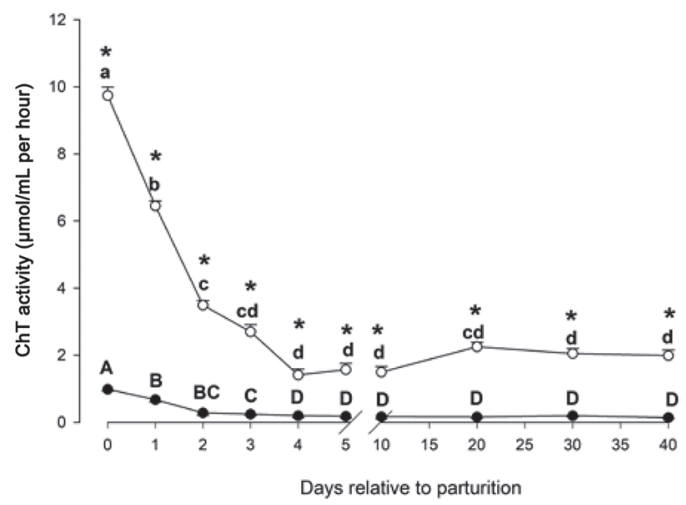

B

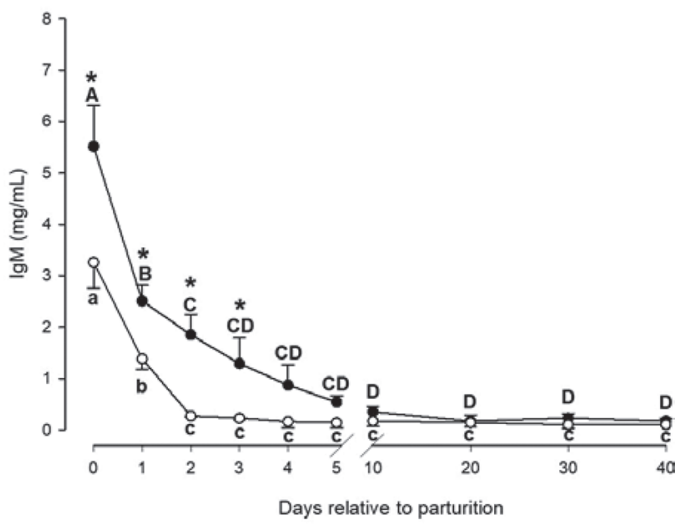

Figure 2. Concentrations of colostrum and milk IgG (A) and IgM (B) and chitotriosidase (ChT) activity (C) in Canaria sheep ( $)$ and Majorera goats $(O)$ during the experimental period. Different uppercase letters $(\mathrm{A}-\mathrm{D})$ indicate significant differences $(P<0.05)$ between time points in Canaria sheep. Different lowercase letters $(\mathrm{a}-\mathrm{d})$ indicate significant differences $(P<0.05)$ between time points in Majorera goats. *Indicates a significant difference $(P<0.05)$ between Canaria sheep and Majorera goats at each time point. Data are mean \pm SEM.

sheep $(81.1 \%$ and $47.2 \%$, respectively) than in goats ( $76.5 \%$ and $39.4 \%$, respectively). Similarly, the study of Getachew et al. (2017) found that the total prevalence of infections caused by nematodes (i.e., Haemonchus spp., Bunostomum spp., Cooperia spp., Esophagostomum spp., Trichostrongylus spp.) was higher in sheep $(61.9 \%)$ than in goats $(42.1 \%)$. These facts need to be considered when these 2 species are raised together.

The complement system plays a crucial role in both adaptive and innate immunity. In fact, it is considered one of the major mechanisms that orchestrates most of the immunological and inflammatory processes (Ricklin et al., 2010). In livestock, the complement system has been mainly studied in cows (Booth et al., 1979; Campbell et al., 1979; Mueller et al., 1983). Hernández-Castellano et al. (2015a) and Moreno-Indias et al. (2012b) showed how both TC and AC activity in blood are undetectable in lambs and goat kids at birth. Unfortunately, few studies have explored this immune variable in adult sheep and goats. Although classical studies have described the alternative comple- ment system in goats as an important pathway in the complement system (Venugopal et al., 1992), we found no studies relative to complement system activity in the adult goat around parturition in the literature. In sheep, Oswald et al. (1990) reported constant values for both TC and AC activity from wk 17 to 77 of life. However, we found no information in the literature about the evolution of both $\mathrm{TC}$ and $\mathrm{AC}$ activity in sheep around parturition. The complement system is a key component of the immune response, which is present in all vertebrates (Mayilyan et al., 2008). According to our results and because of the importance of this system in the innate and adaptive immune systems, it seems that sheep and goats tightly regulate complement system activity around parturition.

Immune components present in colostrum and milk not only protect newborn ruminants against external infections, but also protect the udder itself against those infections (Hernández-Castellano et al., 2011, 2014b). In this study, both immunoglobulin concentrations (IgG and IgM) decreased rapidly after the first milkings 
postpartum, similar to what has been described in cows (Butler and Kehrli, 2005; Hernández-Castellano et al., 2017b; Ozçelik et al., 2017), goats (Sánchez-Macías et al., 2014), sheep (Alves et al., 2015), camels (El-Hatmi et al., 2006), and buffalo (Dang et al., 2009). As described by Barrington and Parish (2001) and Castro et al. (2011), at the onset of lactation prolactin not only stimulates increased milk secretion by the mammary gland, but also reduces the mammary $\operatorname{IgG}_{1}$ receptor. Therefore, reduced milk IgG and IgM concentrations postpartum may be caused by reduced expression of the mammary $\operatorname{IgG}_{1}$ receptor (only in case of $\operatorname{IgG}$ ) and the dilution factor caused by increased mammary gland secretion (both IgG and IgM). Although IgG concentrations in colostrum were similar in both species, IgM concentrations were greater in sheep than in goats. According to the IgM concentrations described in the literature for sheep and goat colostrum, IgM concentrations are often greater in sheep colostrum than in goat colostrum (Butler and Kehrli, 2005; Sánchez-Macías et al., 2014; Hernández-Castellano et al., 2016). However, none of these studies were performed in both species (sheep and goats) at the same time and under similar management conditions. Therefore, we speculate that both sheep and goats have similar IgG transfer rates from blood into colostrum, but IgM is either highly transferred from blood into colostrum or highly synthesized by mammary epithelial cells in sheep compared with goats. Further studies will be necessary to test this hypothesis.

As in blood, this study shows for the first time the evolution of ChT activity in sheep colostrum and milk. In African women, Musumeci et al. (2005) described slightly greater values in colostrum and milk (1.23 and $0.28 \mu \mathrm{mol} / \mathrm{mL}$ per hour, respectively) than those showed in our study for sheep. In goats, Moreno-Indias et al. (2012c) showed values in colostrum $(9.43 \mu \mathrm{mol} /$ $\mathrm{mL}$ per hour) similar to the ones showed in the present study. Although circulating $\operatorname{IgG}, \operatorname{IgM}$, and IgA concentrations are increased in newborn lambs and goat kids after colostrum feeding, several authors have shown that plasma ChT activity in these animals does not increase during the first days after birth (Argüello et al., 2008; Rodríguez et al., 2009; Hernández-Castellano et al., 2015a). This fact suggests that ChT transferred to newborn lambs and goat kids via colostrum and milk is not absorbed at the intestinal level. Therefore, it seems that the role of maternal ChT in newborn lambs and goat kids is to contribute to the protection of the digestive system against infections caused by fungi and nematodes. Increased ChT activity in colostrum and milk is not only relevant for the newborn immune protection, but it is also important regarding udder protection against pathogens. As described in mice, high ChT activity is related to increased macrophage activation (Korolenko et al., 2000) and promotion of pathologic type-2 helper T cells (Wiesner et al., 2015). For instance, Vandevenne et al. (2011) showed the antifungal properties of ChT against infections caused by Candida albicans. Similar properties were observed by Upadhya et al. (2018) for infections caused by Cryptococcus neoformans. Because Candida albicans and Cryptococcus neoformans are common mastitis pathogens in ruminants (Plastridge, 1958; Singh et al., 1994; Spanamberg et al., 2014; Eldesouky et al., 2016), increased ChT activity in goats might contribute to a better immune protection of the udder against mastitis-causing pathogens than in sheep.

\section{CONCLUSIONS}

Farmers raising mixed flocks (sheep and goats) should focus on the days around parturition, because the lowest blood $\operatorname{IgG}$ concentrations were registered in those days for both species. This fact, together with the high risk of metabolic diseases that impair the immune system after parturition, makes sheep and goats especially susceptible to infectious diseases during this period. In addition, chitotriosidase activity was much greater in the blood, colostrum, and milk of goats than in sheep. It seems that goats are better protected against parasites and fungal infections than sheep during this period, a finding that deserves further research and that should be translated into new management strategies in mixed flocks.

\section{ACKNOWLEDGMENTS}

Lorenzo E. Hernández-Castellano acknowledges financial support from the Formación del Profesorado Universitario (FPU) program (Ministry of Education, Spain) and from the Faculty of Science and Technology (Aarhus University, Denmark). Isabel Moreno-Indias was supported by the MS type I program (CP16/00163) from the Instituto de Salud Carlos III (Spain) and cofunded by Fondo Europeo de Desarrollo Regional (FEDER). Antonio Morales-delaNuez acknowledges funding from the Cabildo de Tenerife, under the identification mark Tenerife 2030 (Program TF INNOVA 2016-2021), with MEDI and FDCAN funds. This experiment was funded by the grant AGL2006-08444/GAN from the Ministerio de Educación y Ciencia (Spain).

\section{REFERENCES}

Alves, A. C., N. G. Alves, I. J. Ascari, F. B. Junqueira, A. S. Coutinho, R. R. Lima, J. R. O. Perez, S. O. De Paula, I. F. FurushoGarcia, and L. R. Abreu. 2015. Colostrum composition of Santa 
Ines sheep and passive transfer of immunity to lambs. J. Dairy Sci. 98:3706-3716.

Argüello, A., N. Castro, M. Batista, I. Moreno-Indias, A. MoralesDelaNuez, D. Sanchez-Macias, E. Quesada, and J. Capote. 2008. Chitotriosidase activity in goat blood and colostrum. J. Dairy Sci. 91:2067-2070.

Barrington, G. M., and S. M. Parish. 2001. Bovine neonatal immunology. Vet. Clin. North Am. Food Anim. Pract. 17:463-476.

Booth, N. A., R. D. Campbell, and J. E. Fothergill. 1979. The purification and characterization of bovine $\mathrm{C} 4$, the fourth component of complement. Biochem. J. 177:959-965.

Butler, J. E., and M. E. Kehrli. 2005. Immunoglobulins and immunocytes in the mammary gland and its secretions. Pages 1764-1793 in Mucosal Immunology. 3rd ed. Vol. 2. J. Mestecky, M. E. Lamm, P. Ogra, W. Strober, J. Bienenstock, J. McGhee, L. Mayer, ed. Academic Press, Cambridge, MA.

Campbell, R. D., N. A. Booth, and J. E. Fothergill. 1979. Purification and characterization of subcomponent $\mathrm{C} 1 \mathrm{q}$ of the first component of bovine complement. Biochem. J. 177:531-540.

Castel, J. M., F. A. Ruiz, Y. Mena, and M. Sánchez-Rodríguez. 2010. Present situation and future perspectives for goat production systems in Spain. Small Rumin. Res. 89:207-210.

Castro, N., J. Capote, R. M. Bruckmaier, and A. Argüello. 2011. Management effects on colostrogenesis in small ruminants: A review. J. Appl. Anim. Res. 39:85-93.

Castro, N., J. Capote, D. Martin, and A. Argüello. 2006. The influence of dietary conjugated linoleic acid on blood serum and colostrum immunoglobulin $\mathrm{G}$ concentration in female goats before and after parturition. J. Anim. Physiol. Anim. Nutr. (Berl.) 90:429-431.

Chniter, M., I. Salhi, H. Harrabi, T. Khorchani, A. L. Laine, R. Nowak, and M. Hammadi. 2016. Physiological changes in the peri-partum period and colostral IgG transfer in prolific D'man sheep: Effects of parity and litter size. Trop. Anim. Health Prod. 48:387-394.

Ciupersescu, D. D. 1977. Dynamics of serum immunoglobulin concentrations in sheep during pregnancy and lactation. Res. Vet. Sci. $22: 23-27$.

Dang, A. K., S. Kapila, M. Purohit, and C. Singh. 2009. Changes in colostrum of Murrah buffaloes after calving. Trop. Anim. Health Prod. 41:1213-1217.

Diakoua, A., E. Papadopoulos, N. Panousis, C. Karatzias, and N. Giadinis. 2013. Toxoplasma gondii and Neospora caninum seroprevalence in dairy sheep and goats mixed stock farming. Vet. Parasitol. 198:387-390.

El-Hatmi, H., A. Levieux, and D. Levieux. 2006. Camel (Camelus dromedarius) immunoglobulin $\mathrm{G}$, alpha-lactalbumin, serum albumin and lactoferrin in colostrum and milk during the early post partum period. J. Dairy Res. 73:288-293.

Eldesouky, I., N. Mohamed, D. Khalaf, A. Salama, A. Elsify, R. Ombarak, S. El-Ballal, M. Effat, and M. Al Shabrawy. 2016. Candida mastitis in dairy cattle with molecular detection of Candida albicans. Kafkas Üniversitesi Veteriner Fakültesi Dergisi 22:461-464.

Esposito, G., P. C. Irons, E. C. Webb, and A. Chapwanya. 2014. Interactions between negative energy balance, metabolic diseases, uterine health and immune response in transition dairy cows. Anim. Reprod. Sci. 144:60-71.

Fresno, M. R., J. Gómez, A. Molina, N. Darmanin, J. F. Capote, and J. V. Delgado. 1994. Preliminary study of the Majorera milk goat productive performance. Arch. Zootec. 43:181-186.

Getachew, M., R. Tesfaye, and E. Sisay. 2017. Prevalence and risk factors of gastrointestinal nematodes infections in small ruminants in Tullo district, western Harerghe, Ethiopia. J. Vet. Sci. Technol. $8: 1-4$

Grummer, R. R. 1995. Impact of changes in organic nutrient metabolism on feeding the transition dairy cow. J. Anim. Sci. 73:28202833.

Hernández-Castellano, L. E., A. Almeida, M. Ventosa, A. Coelho, N. Castro, and A. Argüello. 2014a. The effect of colostrum intake on blood plasma proteome profile in newborn lambs: Low abundance proteins. BMC Vet. Res. 10:85.
Hernández-Castellano, L. E., A. M. Almeida, N. Castro, and A. Argüello. 2014b. The colostrum proteome, ruminant nutrition and immunity: A review. Curr. Protein Pept. Sci. 15:64-74.

Hernández-Castellano, L. E., A. M. Almeida, J. Renaut, A. Argüello, and N. Castro. 2016. A proteomics study of colostrum and milk from the two major small ruminant dairy breeds from the Canary Islands: A bovine milk comparison perspective. J. Dairy Res. 83:366-374

Hernández-Castellano, L. E., L. L. Hernandez, H. Sauerwein, and R. M. Bruckmaier. 2017a. Endocrine and metabolic changes in transition dairy cows are affected by prepartum infusions of a serotonin precursor. J. Dairy Sci. 100:5050-5057.

Hernández-Castellano, L. E., L. L. Hernandez, S. Weaver, and R. M. Bruckmaier. 2017b. Increased serum serotonin improves parturient calcium homeostasis in dairy cows. J. Dairy Sci. 100:1580-1587.

Hernández-Castellano, L. E., A. Morales-delaNuez, D. SánchezMacías, I. Moreno-Indias, A. Torres, J. Capote, A. Argüello, and N. Castro. 2015a. The effect of colostrum source (goat vs. sheep) and timing of the first colostrum feeding ( $2 \mathrm{~h}$ vs. $14 \mathrm{~h}$ after birth) on body weight and immune status of artificially reared newborn lambs. J. Dairy Sci. 98:204-210.

Hernández-Castellano, L. E., I. Moreno-Indias, A. Morales-delaNuez, D. Sánchez-Macías, A. Torres, J. Capote, A. Argüello, and N. Castro. 2015b. The effect of milk source on body weight and immune status of lambs. Livest. Sci. 175:70-76.

Hernández-Castellano, L. E., A. Torres, A. Alavoine, M. D. Ruiz-Diaz, A. Argüello, J. Capote, and N. Castro. 2011. Effect of milking frequency on milk immunoglobulin concentration (IgG, IgM and IgA) and chitotriosidase activity in Majorera goats. Small Rumin. Res. 98:70-72

Herr, M., H. Bostedt, and K. Failing. 2011. IgG and IgM levels in dairy cows during the periparturient period. Theriogenology 75:377-385.

Hurley, W. L., and P. K. Theil. 2011. Perspectives on immunoglobulins in colostrum and milk. Nutrients 3:442-474.

INRA (Institut national de la recherche agronomique). 2007. Alimentation des bovins, ovins et caprins - Besoins des animaux - Valeurs des aliments. Tables INRA 2007. Editions Quae, Versailles, France.

Korolenko, T. A., S. Y. Zhanaeva, O. V. Falameeva, V. I. Kaledin, E. E. Filyushina, I. I. Buzueva, and G. A. Paul. 2000. Chitotriosidase as a marker of macrophage stimulation. Bull. Exp. Biol. Med. 130:948-950.

Lérias, J. R., L. Hernández-Castellano, A. Morales-delaNuez, S. Araújo, N. Castro, A. Argüello, J. Capote, and A. Almeida. 2013. Body live weight and milk production parameters in the Majorera and Palmera goat breeds from the Canary Islands: Influence of weight loss. Trop. Anim. Health Prod. 45:1731-1736.

Lérias, J. R., L. E. Hernández-Castellano, A. Suárez-Trujillo, N. Castro, A. Pourlis, and A. M. Almeida. 2014. The mammary gland in small ruminants: major morphological and functional events underlying milk production-A review. J. Dairy Res. 81:304-318.

Malaguarnera, L., M. Di Rosa, A. M. Zambito, N. dell'Ombra, F. Nicoletti, and M. Malaguarnera. 2006. Chitotriosidase gene expression in Küpfer cells from patients with non-alcoholic fatty liver disease. Gut 55:1313-1320.

Manat, T. D., S. S. Chaudhary, V. K. Singh, S. B. Patel, and G. Puri. 2016. Hematobiochemical profile in Surti goats during postpartum period. Vet. World 9:19-24.

Mayilyan, K. R., Y. H. Kang, A. W. Dodds, and R. B. Sim. 2008. The complement system in innate immunity. Pages 219-236 in Innate Immunity of Plants, Animals, and Humans. Vol. 21. H. Heine, ed. Springer Berlin, Heidelberg, Germany.

Moreno-Indias, I., A. W. Dodds, A. Argüello, N. Castro, and R. B. Sim. 2012a. The complement system of the goat: Haemolytic assays and isolation of major proteins. BMC Vet. Res. 8:91.

Moreno-Indias, I., A. Morales-delaNuez, L. E. Hernández-Castellano, D. Sánchez-Macías, J. Capote, N. Castro, and A. Argüello. 2012b. Docosahexaenoic acid in the goat kid diet: Effects on immune system and meat quality. J. Anim. Sci. 90:3729-3738.

Moreno-Indias, I., D. Sánchez-Macías, N. Castro, A. Morales-delaNuez, L. E. Hernandez-Castellano, J. Capote, and A. Argüello. 
2012c. Chemical composition and immune status of dairy goat colostrum fractions during the first $10 \mathrm{~h}$ after partum. Small Rumin. Res. 103:220-224.

Mueller, R., E. J. Carroll, and L. Panico. 1983. Hemolytic complement titers and complement C3 levels in endotoxin-induced mastitis. Am. J. Vet. Res. 44:1442-1445.

Musumeci, M., L. Malaguarnera, J. Simpore, R. Barone, M. Whalen, and S. Musumeci. 2005. Chitotriosidase activity in colostrum from African and Caucasian women. Clin. Chem. Lab. Med. 43:198-201.

Nesargikar, P. N., B. Spiller, and R. Chavez. 2012. The complement system: History, pathways, cascade and inhibitors. Eur. J. Microbiol. Immunol. (Bp.) 2:103-111.

Oswald, I. P., F. Lantier, and G. Bourgy. 1990. Classical and alternative pathway hemolytic activities of ovine complement-Variations with age and sex. Vet. Immunol. Immunopathol. 24:259-266.

Ozçelik, R., R. M. Bruckmaier, and L. E. Hernandez-Castellano. 2017. Prepartum daylight exposure increases serum calcium concentrations in dairy cows at the onset of lactation. J. Anim. Sci. 95:4440-4447.

Piñan, D. F. O. 2010. Guia de Campo de las Razas Autóctonas Españolas. Ministerio de Medio Ambiente y Medio Rural y Marino, Madrid, Spain.

Plastridge, W. N. 1958. Bovine mastitis: A review. J. Dairy Sci. 41:1141-1181.

Renkema, G. H., R. G. Boot, F. L. Au, W. E. Donker-Koopman, A. Strijland, A. O. Muijsers, M. Hrebicek, and J. M. Aerts. 1998. Chitotriosidase, a chitinase, and the 39-kDa human cartilage glycoprotein, a chitin-binding lectin, are homologues of family 18 glycosyl hydrolases secreted by human macrophages. Eur. J. Biochem. 251:504-509

Ricklin, D., G. Hajishengallis, K. Yang, and J. D. Lambris. 2010. Complement: A key system for immune surveillance and homeostasis. Nat. Immunol. 11:785-797.

Rodinova, H., V. Kroupova, J. Travnicek, M. Stankova, and L. Pisek 2008. Dynamics of IgG in the blood serum of sheep with different selenium intake. Veterinarni Medicina 53:260-265.

Rodríguez, C., N. Castro, J. Capote, A. Morales-delaNuez, I. MorenoIndias, D. Sanchez-Macias, and A. Arguello. 2009. Effect of colostrum immunoglobulin concentration on immunity in Majorera goat kids. J. Dairy Sci. 92:1696-1701.

Sánchez-Macías, D., I. Moreno-Indias, N. Castro, A. Morales-delaNuez, and A. Argüello. 2014. From goat colostrum to milk: Physical, chemical, and immune evolution from partum to 90 days postpartum. J. Dairy Sci. 97:10-16.

Singh, M., P. P. Gupta, J. S. Rana, and S. K. Jand. 1994. Clinico-pathological studies on experimental cryptococcal mastitis in goats. Mycopathologia 126:147-155.

Søndergaard, E., M. K. Sørensen, I. L. Mao, and J. Jensen. 2002. Genetic parameters of production, feed intake, body weight, body composition, and udder health in lactating dairy cows. Livest. Sci. $77: 23-34$

Spanamberg, A., C. F. Fraga, L. Ferreiro, M. S. Aguinsky, E. M. C. Sanches, C. Roehe, C. Lautert, and J. M. Santurio. 2014. Yeasts in the raw ewe's milk. Acta Sci. Vet. 42:1236.

Thomas, N., S. Teshale, and B. Kumsa. 2007. Abomasal nematodes of sheep and goats slaughtered in Awassa (Ethiopia): Species composition, prevalence and vulvar morphology. Helminthologia 44:70-75.

Upadhya, R., L. G. Baker, W. C. Lam, C. A. Specht, M. J. Donlin, and J. K. Lodge. 2018. Cryptococcus neoformans Cda1 and its chitin deacetylase activity are required for fungal pathogenesis. MBio 9:e02087.

Vandevenne, M., V. Campisi, A. Freichels, C. Gillard, G. Gaspard, J. M. Frere, M. Galleni, and P. Filee. 2011. Comparative functiona analysis of the human macrophage chitotriosidase. Protein Sci. 20:1451-1463.

Venugopal, G., G. C. Ram, and M. P. Bansal. 1992. Determination of optimal in vitro conditions for caprine alternative complement pathway assay. Vet. Immunol. Immunopathol. 32:359-364.

Wankhade, P. R., A. Manimaran, A. Kumaresan, S. Jeyakumar, K. P. Ramesha, V. Sejian, D. Rajendran, and M. R. Varghese. 2017. Metabolic and immunological changes in transition dairy cows: A review. Vet. World 10:1367-1377.

Weaver, S. R., A. S. Prichard, N. L. Maerz, A. P. Prichard, E. L. Endres, L. E. Hernandez-Castellano, M. S. Akins, R. M. Bruckmaier, and L. L. Hernandez. 2017. Elevating serotonin pre-partum alters the Holstein dairy cow hepatic adaptation to lactation. PLoS One 12:e0184939.

Wiesner, D. L., C. A. Specht, C. K. Lee, K. D. Smith, L. Mukaremera S. T. Lee, C. G. Lee, J. A. Elias, J. N. Nielsen, D. R. Boulware, P. R. Bohjanen, M. K. Jenkins, S. M. Levitz, and K. Nielsen. 2015. Chitin recognition via chitotriosidase promotes pathologic type-2 helper $\mathrm{T}$ cell responses to cryptococcal infection. PLoS Pathog. 11:e1004701. 